\title{
THE INFLUENCE OF NEW PUBLIC MANAGEMENT TOWARDS THE QUALITY OF BUREAUCRATIC TOURISM SERVICE IN LAKE TOBA NORTH SUMATERA (A STUDY IN FOUR DISTRICS)
}

\author{
Erika Revida \\ Public Administration Departement \\ USU \\ Medan,Indonesia \\ erikarevida@yahoo.com
}

\author{
Alwi Hashim Batu Bara \\ Public Administration Departement \\ USU \\ Medan,Indonesia \\ erikarevida@yahoo.com
}

\author{
Sukarman Purba \\ Education Management Departement \\ UNIMED \\ Medan,Indonesia \\ arman_prb@yahoo.com
}

\begin{abstract}
The objectives of the research was to analyze the influence of New Public Management Towards The Quality of Bureaucratic Tourism Services In Lake Toba Parapat North Sumatra. The method used of this research were combination between quantitative and qualitative research. Samples were taken from all the bureaucratic in Lake Toba Parapat North Sumatera of 120 people from 4 district around Lake Toba North Sumatera. Data collection techniques used from documentary studies, questionnaires, interviews and observations, while the data analysis technique used were Product Moment and Simple Linier Regression analysis. The results showed that there was a positive and significant influence between New Public Management and The Quality of Bureaucratic Tourism Services in Lake Toba Parapat North Sumatra. The recommendations of this research were it needs to enhance New Public Management by The Efficiency Drive, Downsizing and Decentralization, In Search of Excellence, and Public Service Orientation and to enhance The Quality of Bureaucratic Tourism Service by giving tangibles, reliability, responsive and assurance and empathy service to the tourist.
\end{abstract}

Keywords - new public management, public management, and the quality of bureaucratic tourism service.

\section{INTRODUCTION}

Bureaucracy is an important element of government and has main duty and function of providing quality services at various aspects in society. Rasyid (1997)1) stated that the main task of government were development, empowerment and services. The services must provide standard needs and wishes of the community as well as tourists. Bureaucratic Tourism Services are services provide to the tourists. It must be qualified because it will determine the satisfaction of tourists and tourist visits repeated.

The quality tourism services is a means of direct and indirect promotion to other tourists called by word of mouth by word of mouth. It means that if the tourism service is not or less quality given to tourist it will have an impact on the lack or decrease in the number of tourist visits which in turn have an impact on decreasing income and local revenue (Pendapatan Asli Daerah). Therefore, improving the Quality of Tourism Services Bureaucracy becomes an important issue to research and develop today.

Acoording to tourism law no. 10 of 20092), stated that the purpose of tourism were to enhance economic growth, improve the welfare of the people, eradicate poverty, overcome unemployment, conserve nature, environment, and resources, promote culture, lift the image of the nation, homeland, strengthen the identity and unity of the nation and strengthen friendship among nations. The objective of tourism law make the quality of tourist service must be increased and also will impact to the increase of tourist visits.

Indeed many factors have been done by the government to enhance the Quality of bureaucratic tourism services. But infact till now on still not showing a significant results. Therefore this research needs to be done with the tittle "The Influence of New Public Management Towards The Quality Of Bureaucratic Tourism Services In Lake Toba Sumatera Utara.

\section{RESEARCH METHODS}

This research used a combination between quantitative and qualitative research methods. Creswell (2002)3) mentioned that this method with the term dominant-less dominant design. The population of the research were all of bureaucratic in tourism department at Four districts around Lake Toba Sumatera Utara that were Simalungun, Toba Samosir, Samosir, and Humbang Hasundutan, while the research sample were as much as 120 bureaucrats. Data collection techniques used were documentation studies, research 
instruments, interviews and observation. Quantitative data analysis techniques used were Product Moment and Simple Linear Regression Analysis, while qualitative data analysis used data organization, reduction and interpretation of research data.

\section{RESULTS AND DISCUSSION}

Tourism was a journey undertaken by a person or groups temporarily from one place to another with the intention not to try and earn a living in the place visited, but only to enjoy the journey for the sake of recreation and meet the diverse needs (Bakaruddin, 2008)4).

Thoha (1987)5) stated that improving the quality of service to the community was one of the important issues in the process of public administration reform, similarly with the quality of bureaucratic tourism services. The quality of tourism services bureaucracy was the quality of tourism assistance provided to the tourists. The Quality of Bureucratic Tourism Services must satisfy the desires/needs of the physical and spiritual tourists. Therefore, New Public Management needed (Ferlie,1997)6).

New Public Management (Ferlie, 1997)6) was a new public management comprising four principles that were (1) The Efficiency Drive; (2). Downsizing and Decentralization; (3). In Search of Excellence; and (4). Public Service Orientation. The implementation of New Public Management could enhance The quality of bureaucratic tourism services in Lake Toba North Sumatra.

The Efficiency Drive emerged in the mid of 1980s, that wanted the public sector to be managed in a business with the principle of efficiency that was oriented to the achievement of profits as much as possible, and applying private sector management functions into the public sector. Efficient was the best comparison between input and output. In this case the principle of Efficiency drive did not mean ignoring the effectiveness of bureaucratice tourism services.

Downsizing and Decentralization were a shift from hierarchical management (tall) to a more streamlined management. The most ideal bureaucracy was to apply a shorter structure and delegate authority to the bureaucracy that directly handle the service to the tourist.

In Search of Excelllence was the principle that always done and looked for something new that innovative to the tourism service more quickly, friendly, responsive and accountable felt by tourists so that there was no empty service as soon as needed by tourists. In search of excellent in tourism services was always proactive and looking forward in order to provide better tourism services.

The principle of Public Service Orientation always strives to provide quality services to the tourists by using the principles of service conducted by the private sector (private) in serving the tourists. Therefore, this principle emphasizes the important of changing bureaucratic culture from those who did not like to serve, from those who like to slow down to like and to accelerate service to the tourists.
Zeithaml, et al. (1990)7) stated that there were five dimensions of Quality Service That were : Tangibles: appearance of physical facilities, equipment, personnel, and communication materials; Reliability : ability to perform the promised service dependably and accurately; Responsiveness: willingness to help customers and provide prompt service; Assurance: knowledge and courtesy of employees and their ability to convey trust and confidence; Empathy : caring, individualized attention the firm provides its customers.

According to the results of research conducted on 120 bureaucrats showed that the variable of New Public Management (X) has a mean value was 93.17, Median 93, and Mode was 91. The minimum score was 59, the maximum score was 116 , and the score range was 57 such listed in table 1 below.

Table 1. The Result of Research Data Descriptive Analysis

\begin{tabular}{|c|c|c|}
\hline Description & $\begin{array}{c}\text { New Public } \\
\text { Management (X) }\end{array}$ & $\begin{array}{c}\text { Quality of } \\
\text { Tourism } \\
\text { Service (Y) }\end{array}$ \\
\hline $\mathrm{N}$ & 120 & 120 \\
\hline Mean & 93.17 & 53.99 \\
\hline Median & 93.00 & 54.00 \\
\hline Mode & 91 & 49 \\
\hline Deviation Standard & 11.514 & 7.873 \\
\hline Variance & 132.577 & 61.992 \\
\hline Range & 57 & 40 \\
\hline Minimum & 59 & 32 \\
\hline Maximum & 116 & 72 \\
\hline Sum & 11180 & 6479 \\
\hline
\end{tabular}

The description data were presented in 8 classes in the frequency distribution as in table 2 below.

Table 2. The Distributions of New Public Management (X) Variable

\begin{tabular}{|c|c|c|c|c|}
\hline Class & $\begin{array}{c}\text { Interval } \\
\text { Class }\end{array}$ & $\begin{array}{c}\text { Absolute } \\
\text { Frequenc } \\
\mathrm{y}\end{array}$ & $\begin{array}{c}\text { Relative } \\
\text { Frequency }(\%)\end{array}$ & $\begin{array}{l}\text { Cummul } \\
\text { ative } \\
\text { Frequen } \\
\text { cy }(\%)\end{array}$ \\
\hline 1 & $59-66$ & 2 & 1,67 & 1,67 \\
\hline 2 & $67-74$ & 4 & 3,33 & 5,00 \\
\hline 3 & $75-82$ & 16 & 13,33 & 18,33 \\
\hline 4 & $83-90$ & 24 & 20,00 & 38,33 \\
\hline 5 & $91-98$ & 31 & 25,83 & 64,16 \\
\hline 6 & $99-106$ & 27 & 22,50 & 86,66 \\
\hline 7 & $\begin{array}{c}107- \\
114 \\
\end{array}$ & 15 & 12,50 & 99,16 \\
\hline 8 & $\begin{array}{c}115- \\
122\end{array}$ & 1 & 0,84 & 100,00 \\
\hline \multicolumn{2}{|c|}{ Total } & 120 & 100,00 & \\
\hline
\end{tabular}

From table 2 it can be seen that the average score was in grade 5 , so it could be concluded that there were $38,33 \%$ of respondents answered was below average value and 61,67\% respondent answered above average value. To illustrate the 
distribution of data scores of New Public Management (X) variables shown in the following histogram figure.



Figure 1. Histogram of New Public Management Score (X)

Furthermore, for the Quality of Bureaucratic Tourism Service variable (Y), the mean value was 53.99, Median 54, Mode was 49, while the minimum score was 32, the maximum score 72 , and the range was 40 . The data description was arranged in frequency list in 8 classes such as presented in table 3 below.

Table 3. Frequency Distribution Frequency of Quality of Bureaucratic Tourism Services (Y)

\begin{tabular}{|c|c|c|c|c|}
\hline Class & $\begin{array}{c}\text { Interval } \\
\text { Class }\end{array}$ & $\begin{array}{l}\text { Absolute } \\
\text { Frequency }\end{array}$ & $\begin{array}{c}\text { Relative } \\
\text { Frequency } \\
(\%)\end{array}$ & $\begin{array}{c}\text { Cummul } \\
\text { ative } \\
\text { Frequen } \\
\text { cy }(\%)\end{array}$ \\
\hline 1 & $32-37$ & 3 & 2,50 & 2,50 \\
\hline 2 & $38-43$ & 6 & 5,00 & 7,50 \\
\hline 3 & $44-49$ & 27 & 22,50 & 30,00 \\
\hline 4 & $50-55$ & 37 & 30,83 & 60,83 \\
\hline 5 & $56-61$ & 26 & 21,67 & 82,50 \\
\hline 6 & $62-67$ & 14 & 11,67 & 94,17 \\
\hline 7 & $68-73$ & 7 & 5,83 & 100,00 \\
\hline 8 & $74-79$ & 0 & 0,00 & 100,00 \\
\hline & Total & 120 & 100,00 & \\
\hline
\end{tabular}

Based on table 3 the frequency distribution showed that the average value was in grade 4 , so it could be concluded that there were as many as $30 \%$ of respondents answers was below the average value and as much as $70 \%$ of respondents' answers were on and above the average value. Histogram of The quality service tourism bureaucracy $(\mathrm{Y})$ variable was shown in the following image.

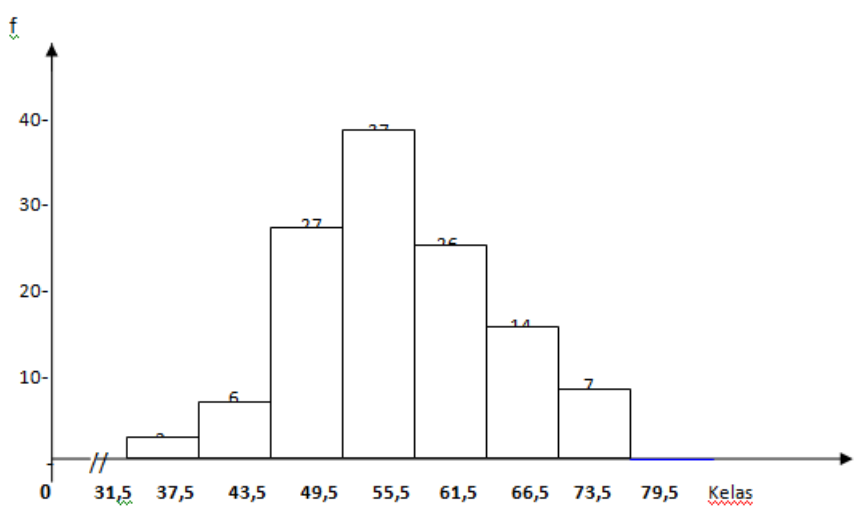

Figure 2. Histogram Score of Quality of Bureaucratic Tourism Services (Y)

Next, the trend level of the New Public Management (X) was presented in the following table 4.

Table 4. The Tendency Rates of New Public Management(X)

\begin{tabular}{|c|c|c|c|c|}
\hline Class & Class Interval & $\begin{array}{c}\text { Observation } \\
\text { Frequency }\end{array}$ & $\begin{array}{c}\text { Relative } \\
\text { Frequency } \\
(\%)\end{array}$ & Category \\
\hline 1 & $61 \geq$ & 26 & 21,67 & High \\
\hline 2 & $49-60$ & 67 & 55,83 & Enough \\
\hline 3 & $37-48$ & 25 & 20,83 & Less \\
\hline 4 & $\leq 36$ & 2 & 1,67 & Low \\
\hline & Total & 120 & 100,00 & \\
\hline
\end{tabular}

Table 4 showed that there were 26 respondents $(21.67 \%)$ answered that the New Public Management were in high category, 67 respondent said $(55.83 \%)$ were in the enough category , 25 respondent said $(20.83 \%)$ were in the less category, and there were as many as 2 respondernt $(1.67 \%)$ were in the low category. Thus, it could be stated that the category of New Public Management in Lake Toba North Sumatera was in enough category.

Furthermore the level of tendency rates of Quality of bureaucratic tourism services variable was shown in table 5 below.

Table 5. The Tend of Quality of Bureaucracy Tourism Service (Y)

\begin{tabular}{|c|c|c|c|c|}
\hline Class & $\begin{array}{c}\text { Class } \\
\text { Interval }\end{array}$ & $\begin{array}{c}\text { Observation } \\
\text { Frequency }\end{array}$ & $\begin{array}{c}\text { Relative } \\
\text { Frequency } \\
\text { Relatif (\%) }\end{array}$ & Category \\
\hline 1 & $\geq 104$ & 26 & 21,67 & High \\
\hline 2 & $84-103$ & 70 & 58,33 & Enough \\
\hline 3 & $67-83$ & 22 & 18,33 & Less \\
\hline 4 & $\leq 66$ & 2 & 1,67 & Low \\
\hline \multicolumn{2}{|c|}{ Total } & 120 & 100,00 & \\
\hline
\end{tabular}

Table 5 showed that there were 26 respondents's answered $(21.67 \%)$ in the high category of Quality bureaucracy tourism services, there were 70 respondents $(58.33 \%)$ in enough category, as many as 22 respondents $(18.33 \%)$ were in the 
less category, and there were 2 respondents (1.67\%) in the low category of bureaucracy tourism Service. Thus, it could be concluded that quality of bureucracy tourism service in Lake Toba North Sumatera was in the enough category.

\section{Hypothesis TESTING}

To test the hypothesis was done by correlation and simple linier regression analysis, after the requirements analysis, that were the data normality test and linearity test. The results of the calculations concluded that both research variables had data from normally distributed and the relationships between the two variables showed linear relationship.

The regression equation showing the relationship of Bureaucracy Tourism Service Quality with New Public Management was $\hat{\mathrm{Y}}=$ $20,720+0,357 \mathrm{X}$. The Summary of Results of the Linear Regression Analysis showed in table 6 below.

Table 6. The Summary of Results of the Linear Regression Analysis

\begin{tabular}{|c|c|c|c|c|c|}
\hline \multirow[t]{2}{*}{ Model } & \multicolumn{2}{|c|}{$\begin{array}{c}\text { Unstandardized } \\
\text { Coefficients }\end{array}$} & \multirow{2}{*}{$\begin{array}{c}\text { Standardized } \\
\text { Coefficients }\end{array}$} & \multirow[b]{2}{*}{$\mathrm{t}$} & \multirow[b]{2}{*}{ Sig. } \\
\hline & $\mathrm{B}$ & Std. Error & & & \\
\hline $\begin{array}{cc}1 & \text { (Cons } \\
& \tan )\end{array}$ & 20.720 & 5.039 & & 4.112 & .000 \\
\hline$X$ & .357 & .054 & .522 & 6.652 & .000 \\
\hline
\end{tabular}

a. Dependent Variable : Y

The form of linear relationship between New Public Management variable with The Quality of Bureaucratic Tourism Services variable was shown in the following figure.

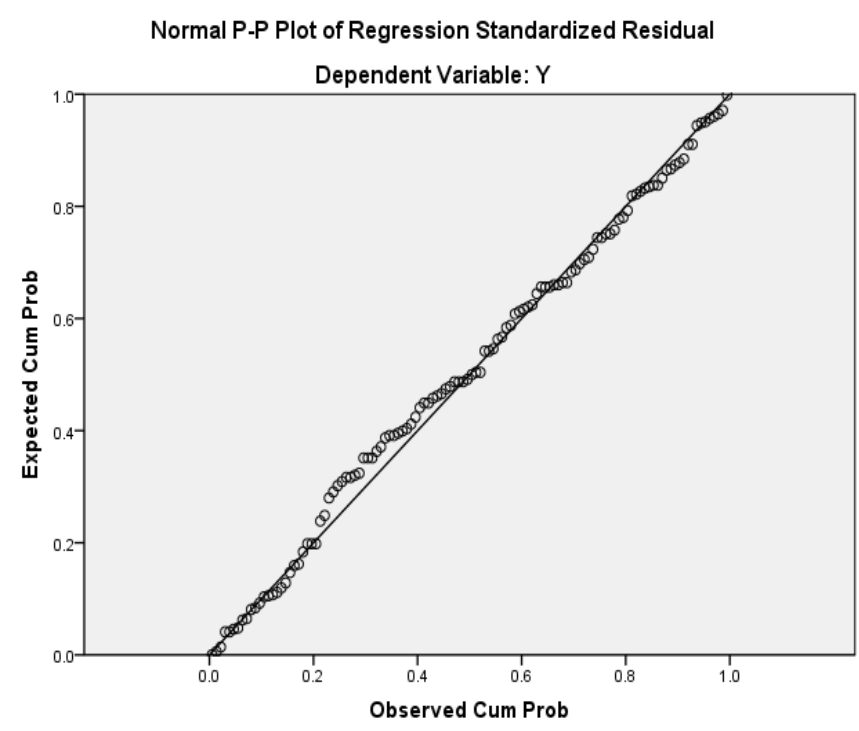

Figure 3. Form of New Public Management (X) with The Quality of Bureaucratic. Tourism Services (Y)
Furthermore, based on the calculation results obtained correlation coefficient ryx $=0.522$. When compared to the table price at $\alpha=0.01$ of 0.210 , it turned the value rcount $>$ rtable or $0.522>0.210$. The result of calculation of significance test with t-test in table 6 showed tcount of 6,652 , and when compared to t table value at $\alpha=0,01$ obtained 2,57. Thus, the value of tcount $>$ ttable or $6.652>2.57$ so that the correlation coefficient were means. These results concluded that the hypothesis that there was a positive and significant influence between New Public Management towards The Quality of Bureaucracy Tourism Services was tested truth. In other words, if the better the implementation of New Public Management the higher the Quality of Bureaucratic Tourism Services provided. The contribution of New Public Management variable to the variable of Bureaucratic Tourism Service Quality was obtained from the large coefficient of determination. The coefficient of determination could be calculated $\mathrm{r}$ yx2 $=(0,522) 2 \times 100 \%=27.25 \%$. That was, $27.25 \%$ variation of The quality of bureaucratic tourism services could be explained by the variation of New Public Management. Meanwhile, the rest of $72.75 \%$ was determined by other variables that had not been covered in this research.

\section{CONCLUSIONS AND RECOMMENDATIONS}

There are several conclusions that can be drawn based on the results of research conducted below:

1) New Public Management had a positive and significant impacted towards The Quality of Bureaucratic Tourism Services In Lake Toba Sumatera Utara

2) The trend level of New Public Management in Lake Toba North Sumatra was in the enough category

3) The trend level of Bureaucratic Tourism Service Quality In Lake Toba North Sumatra was in enough category.

In relation to the conclusion of the research, the suggestions proposed in this research were :

1) New Public Management needs to be done so that the Quality of Bureaucratic Tourism Services in Lake Toba North Sumatra would be better

2) New Public Management to be upgraded by the principle of The Efficiency Drive; (2). Downsizing and Decentralization; (3). In Search of Excellence; And (4). Public Service Orientation.

3) Quality of Bureaucratic Tourism Services In Lake Toba Sumatera Utara needs to improve through the implementation tangibles, reliability, responsive, assurance and empathy.

\section{References}

[1] Rasyid, Muhammad Ryaas. 1997. Makna Pemerintahan. Tinjauan dari Segi Etika dan Kepemimpinan. Jakarta : PT. Yarsif Watampone. Cetakan Ketiga. 
[2] Undang-undang Nomor 10 Tahun 2009 tentang Kepariwisataan. Jakarta: Sekretariat Negara.

[3] Creswell, John W. 2002. Research Design. Qualitative \& Quantitative Approaches. New York : Sage Publication, Inc.

[4] Bakaruddin. 2008. Perkembangan Permasalahan Kepariwisataan. Padang : Universitas Negeri Padang.
[5] Thoha, Miftah. 1987. Perspektif Perilaku Birokrasi. Jakarta : Penerbit Rajawali Press. Cetakan Pertama.

[6] Ferlie, Ewan. 1997. The New Public Management in Action. New York : Oxford University Press.

[7] Zeithaml, Valerie A Parasuraman A dan Leonard L.Berry. 1990. Delivery Quality Service, Balancing Customer Perceptions And Expectation. New York : The Free Press 